\title{
The Heritage of the Cold War in Contemporary Curricula and Educational Reforms
}

Tomislav TopolovČan ${ }^{* 1}$ AND SNJežAna Dubovicki ${ }^{2}$

$\approx \quad$ Using a theoretical-critical and historical approach, this paper analyses the implications of the Cold War in national curricula and educational reforms of the second half of the 2oth century with emphasis on the 21st century. The context of the time after the Second World War and the beginning of the Cold War is shown, as well as the social and political changes that are significant for education and were prompted by the wars. The emergence of the international Organization for Economic Cooperation and Development (OECD) (whose focus is not educational but economic) and the role of behavioural psychology were also analysed, which explained their significance in later educational reforms. The role of the Cold War in reducing socio-humanistic teaching contents and the implementation of natural sciences and mathematics has also been explained. The synthesis of the analysed aspects suggests that the Cold War military and technological race resulted in the implementation of the STEM area, thus the measurability of learning outcomes, which influenced the psychologisation, standardisation, economisation, and globalisation of education. Most of the current (un)successful national educational and curricular reforms were initiated in that direction without respect for the social, cultural, and historical features of individual countries. These changes have left a mark in pedagogy, in which the humanistic approach appears to counteract other approaches. Some educational systems demonstrate a shift from such trends, from the technical-scientific curriculum towards the didactic tradition of Bildung and the philosophy of education. The reasons can be found in the above-average results on international standardised evaluations of those countries that have national curricula, in contrast to what is recommended by the globalisation and standardisation of education as some of the elements of the Cold War heritage.

Keywords: cold war, educational reform, humanistic-oriented curriculum, OECD, PISA

$1 \quad{ }^{\star}$ Corresponding Author. Faculty of Teacher Education, University of Zagreb, Croatia; tomislav.topolovcan@ufzg.hr.

2 Faculty of Education, Josip Juraj Strossmayer University of Osijek, Croatia. 


\section{Dediščina hladne vojne v sodobnih učnih načrtih in izobraževalnih prenovah}

Tomislav TopolovČan IN SNJEŽANA DUbovicki

$\propto$ V tem prispevku analiziramo učinke hladne vojne na nacionalne kurikulume in izobraževalne prenove $\mathrm{v}$ drugi polovici 2o. stoletja s poudarkom na 21. stoletju, pri čemer smo uporabili teoretično-kritičen in zgodovinski pristop. Prikazani so kontekst obdobja po drugi svetovni vojni ter začetek hladne vojne ter družbene in politične spremembe, pomembne za izobraževanje, ki so jih spodbudile vojne. Prav tako smo analizirali ustanovitev mednarodne Organizacije za gospodarsko sodelovanje in razvoj (OECD) (ki se ne osredinja na izobraževanje, ampak na gospodarstvo) in vlogo vedenjske psihologije, ki sta osvetlili njun pomen za poznejše izobraževalne prenove. Pojasnjena je bila tudi vloga hladne vojne pri krčenju družbeno-humanističnih učnih vsebin ter vpeljevanju naravoslovja in matematike. Sinteza analiziranih vidikov kaže, da sta vojaška in tehnološka tekma hladne vojne učinkovali na področje STEM in merljivost učnih rezultatov, kar je vplivalo na psihologizacijo, standardizacijo, ekonomizacijo in na globalizacijo izobraževanja. Večina zdajšnjih (ne)uspešnih nacionalnih izobraževalnih in kurikularnih prenov se je začela $v$ tej smeri ter ni upoštevala socialnih, kulturnih in zgodovinskih značilnosti posameznih držav. Te spremembe so močno vplivale na pedagogiko, za katero se zdi, da humanistični pristop nasprotuje drugim pristopom. $\mathrm{V}$ nekaterih izobraževalnih sistemih je viden odmik od teh trendov, od tehnično-znanstvenega kurikuluma $\mathrm{k}$ didaktični tradiciji in filozofiji izobraževanja. Razloge lahko najdemo $\mathrm{v}$ nadpovprečnih rezultatih, doseženih na mednarodnih standardiziranih evalvacijah v državah z nacionalnimi kurikulumi, v nasprotju s priporočili globalizacije in standardizacije izobraževanja kot nekaterimi elementi dediščine hladne vojne.

Ključne besede: hladna vojna, izobraževalna prenova, humanistično usmerjen kurikulum, OECD, PISA 


\section{Introduction}

Pedagogical science stands before a crossroads. Many phenomena studied in pedagogy are closely related to philosophy, psychology, and sociology (and other sciences). ${ }^{3}$ With the help of knowledge and achievements from, for example, philosophical, psychological, or sociological perspectives, one seeks to face pedagogical issues and dilemmas. Many sciences dabble in education. However, the greatest significance goes to pedagogy, which puts education at the centre of its profession. Didactics, as one of the branches of pedagogy, strives for a more successful approach to the educational process. Attempting to make the teaching process as successful as possible, didactics focus on various didactic phenomena that enhance and enrich teaching. One of these phenomena is certainly a reflection of the current theoretical frameworks of the curriculum, that previously had different orientations, which could be reflected in the learning outcomes but also through the influence of educational reforms.

In contrast, with the turbulent development of the phenomenology of education, the last three decades have been marked by turbulent global economic, technological, social, and political changes. One of the crucial moments from the end of the previous century was the fall of the totalitarian communist bloc in Europe, the collapse of the individual states, and the emergence of new ones, as well as the (apparent) end of the Cold War. Starting at the end of the Second World War, the Cold War had an impact on the development of the economy, technology, culture, society and politics of the western and eastern bloc, and the rest of the world. However, the question is to what extent the circumstances of the Cold War had the implications on the education both at national and global levels and whether they still are manifest (Evans, 2011; Hartman, 2008; Tröhler, 2011; Tröhler \& Barbau, 2011).

Modern theoretical, conceptual approaches and practical implications are based on the Anglo-Saxon approach towards the curriculum. This approach is based on behavioural psychology and cost-benefit correlation analysis of the curriculum. The approach mostly originated from the Cold War's influence on education. The implementation of practical needs arising from the Cold War has controversial practical implications in curricula, which conflict with the historical European (mostly German) concept of education (German: Bildung). In other words, the Anglo-Saxon, Cold War concept of curriculum lacks a humanistic approach towards education. The absence of such an approach is an

3 The relationship between pedagogy, pedagogical science, and some other approaches such as the approach to education from the perspective of that which is called educational science (germ. Erziehungswissenschaft) can be seen at Gudjons (1993). 
enormous defect in modern education and the conceptualisation of future curricula. Therefore, it is evident that there is a lack of discourse and debate on the relationship of behaviourist, Cold War approaches towards (national) curricula and the humanistic concept of curricula to bring about the conclusion on the value of some curriculum elements of modern education.

In the direction of the aforementioned changes and trends, this paper aims to analyse the implications of the Cold War on education. The historical and conceptual development of the curriculum will be analysed as well as the beginning of the formation of the role of the Cold War. Then, the role of psychology on the formation of new approaches towards learning and teaching will be analysed, as well as the reduction of socio-humanistic content in curricula and their substitution with the content from the STEM area. In this context, the PISA assessment and the role of the OECD will also be analysed. Furthermore, the significance of the European (mostly German) didactic thought of the humanistic approach, as well as the methodological turnaround towards the quantitative research, will be analysed.

In this regard, this paper aims to describe and correlate the features of the curriculum, the role of the Cold War in the formation of modern education, and the relationship of the mentioned elements towards the humanistic and holistic approach to curriculum research. The methodology is based on a historical, theoretical, and comparative study of historical facts and theoretical concepts. The synthesis of the mentioned educational phenomena will attempt to explain, define, and understand the contemporary trends of curriculum development and educational reforms.

\section{The Search for the Contemporary Curriculum - A Look to the Past with a Projection to the Present}

If we wanted to define what the modern curriculum implies today, we would first have to answer the question of what a curriculum is. Different definitions are based on different theoretical orientations, and they do not exclude one another, but emphasise the different elements of the curriculum (e.g., Pinar, 2003; Walker, 2003).

The term curriculum is taken from US terminology where didactics has not been developed as a branch of pedagogy, whereas the theory of curriculum covers this area in countries with a longer didactic tradition, which therefore have a different approach to this phenomenon. The original meaning of the Latin word curriculum is a course that represents a relatively optimum way of acting and reaching a goal. 
Poljak (1984) sets the emergence of the term 'curriculum' in pedagogy at the turn from the $16^{\text {th }}$ to the $17^{\text {th }}$ centuries, when it meant the order of learning content by age, which has been, for a long time (even today) identified with the contemporary curriculum. Ratke and Komensky, at the end of the $16^{\text {th }}$ and early 17th centuries, spread the ancient concept of the curriculum towards Western Europe, with their didactic ideas. At that time, the curriculum denoted the scope of knowledge that young people needed to adopt in order to prepare themselves for life and work in their social environment. Since the $18^{\text {th }}$ century, German-speaking areas used the term 'teaching plan and programme', while in the Anglo-Saxon countries still use the term 'curriculum'. From the 1920s, with the appearance of the first scientific analyses of the school curriculum in the US and up to now, the development of the curriculum and its interpretation has undergone several phases (Wiles \& Bondi, 1998). The discussion on the curriculum after the United States also affects Europe, and the concept of curriculum experiences an extension of meaning that has not always coincided with the traditional concept of the curriculum. From that time on, the curriculum implies the prescribing of aims and tasks of learning and teaching, teaching contents and topics, methods, media, and evaluation procedures.

The concept of the curriculum extended to the overall function of the school in the 1930s. In the early 1950s, the technological, developmental, or processual forms of the curriculum were placed in the foreground, meaning the procedures that define the curriculum as the content of learning. In the 1970s and ' 80 s, the concept of curriculum expands to the conditions in which learning takes place and encompasses the problem of applying the curriculum. The curriculum conditioned a new systematisation of knowledge sources, as well as new organisation and methods of work. Since that, nothing has been the same in pedagogy and education as it was prior to the curriculum (Mijatović, 1996). Zimmermann (1977) distinguishes four periods in the curricular development since the 1950s: the $1^{\text {st }}$ period is marked by the philosophy of spiritual-scientific pedagogy; the $2^{\text {nd }}$ period is marked by Robinsohn's documents that interpret the curricular development as a pedagogical-political requirement, not as a concept and a methodical requirement; the $3^{\text {rd }}$ period emphasises getting closer to the practice and school with the help of scientifically-based empirical methods, the creation of subject curricula, the formation of the so-called open curriculum, qualitative methodology (action research); the $4^{\text {th }}$ period begins in the mid-1970s and emphasises the question of curricular planning of the entire teaching.

Speaking of the types of curricula, we can say that different authors cite different types. Glatthorn (2000) states the following types or levels of curriculum: 1) recommended, 2) written or official, 3) derived or taught, 4) supportive, 
5) measured/estimated, 6) taught, and 7) hidden. Furthermore, two categories of curriculum can be mentioned: 1) non-scientific or non-technical and 2) scientific or technical, which also lists subcategories: behavioural, managerial and systematic (Domović, 2009).

Wojtczak (2002) defines curriculum as a teaching plan and programme with a list of aims to be achieved, content to be taught, and methods to be used for learning, teaching and evaluation. Hrvatić and Piršl (2007) define the curriculum as a set of planned and implicit determinants that guide the educational process and refer to the tasks and content that are consistently derived from the aim, also to organisational forms, methods of work and procedures for checking the success of the teaching process. Tanner (1980) is guided by the definition of the curriculum as planned and guided learning whose expected outcomes are described by the systematic structure of knowledge and experience in the school environment, with the goal of the continuous and complete development of students' personal and social competences.

Matijević and Rajić (2015) point out that in the first half of the 2oth century curricular changes took place under the strong influence of the reform pedagogy movement, while in the latter half of the century these changes took place under the influence of pedagogical and psychological scientific discoveries, theories of learning, and curricular theories.

Smith (2000) speaks of the types of curricular orientation and lists four basic curriculum approaches: (1) curriculum as a list of knowledge to be transferred, (2) curriculum as an endeavour for certain achievements in students, (3) a process-oriented curriculum (4) practice-oriented curriculum. If the curriculum has a liberal orientation, the emphasis will be put on the traditional values and elements of Western cultural heritage (founder: C. W. Taylor). The curriculum that has a scientific orientation will emphasise the carrying out of the activities that will prepare a student for life by focusing on setting up tasks (founders: Franklin Bobbitt and Ralph W. Tyler), while the curriculum with a developmental orientation will keep track of the developmental phases of an individual, and accordingly strive to meet his/her interests and needs (founder: G. Stanley Hall). The curriculum orientated towards the social context considers educational institutions (schools, faculties) that have a major impact on the changes in social relations and social justice, and the main task of such a curriculum is to make young people aware and stimulate their sensitivity towards corruption, as well as sexual and any other discrimination (founder: Lester Frank Ward).

To create a productive curriculum, it is important to accept the methodology of its reconstruction, the participation of all interested factors and the understanding of the mentioned construction as a dynamic process of constant 
creation and formation (Miljak, 2005). Curricular reconstruction takes place on the go, as a kind of simultaneous, partner curriculum that has its own: philosophy (aims, tasks, expectations), methodology (action, participatory), practice (event and participation) and result (the state of inner satisfaction, competence).

Marsh (2004) speaks of the fundamental categories that are extremely significant for every approach to curriculum development. He systematised them and divided them into the five most important categories: student's point of view; teacher's competencies; a strategy of making a curriculum, planning and development and curricular management. All five of these curricular components are essential for the successful functioning of the educational institution to which the curriculum refers.

Looking at the curriculum as a whole, it is evident that it had a long and meaningful history. Different theoretical approaches in curricula and didactics also provided specific methods, and teaching based on such approaches focused on specific learning outcomes. The multitude of different approaches to the curriculum offers a teaching staff several ways to successfully approach the implementation of the curriculum that would follow curricular ideas but also had the opportunity to implement the individual interests and needs of its participants. The relatively recent and original approach to understanding the curriculum comes from an aspect of chaos theory (Doll, 1993). From that point of view, William E. Doll recognises the elements of chaos theory in teaching and learning (i.e. teaching itself); he believes that education and learning are very flexible, fluent, creative, self-regulating, autopoietic phenomena that shape the settings of constructivist teaching (Doll, 1993; Topolovčan, Rajić, \& Matijević, 2017). The curriculum with a starting point in critical-constructive didactics ${ }^{4}$ would be the one that makes room for the social interaction of teachers and students, but also of students among themselves, one that respects student interests and desires, which prefers learning by means of discovery; in such a curriculum, emphasis would be on the independent activity of students who would develop self-determination, solidarity, and co-determination.

Regardless of different definitions and approaches towards curricula, the most common practical form is a scientific or technical curriculum, which was evidently established in the circumstances of the Cold War.

4 Didactics as the theory of education can be seen in the context of critical-constructive educational science, we approach it as the theory of teaching, as cybernetics-information theory, the theory of curriculum, and as critical theory of teaching (Gudjons, Teske, \&Winkel, 1992). 


\section{The Genesis of Contemporary Global Approaches to Education}

Shortly after World War Two, the illusory co-operation between the US and the USSR disappeared, and a perilous international rivalry forms based on various political, economic, and ideological elements. The USSR attempted to portray the US and the democratic states as bourgeois and exploitative nations. The US considered the USSR a backward state with a determined ideology while considering itself a state 'free of ideology' (Tröhler, 2014). The US also portrayed itself as a world leader of democracy, freedom, citizenship, development and technological, economic and cultural progress and development.

The turning point of the US self-promotion as the leader of the free and advanced part of the world occurred in 1957 when the USSR launched Sputnik into space. That caused the so-called 'Sputnik shock' in the US. Political and expert establishment in the US analysed the situation and concluded that the USSR made the first launch in space because it had invested more material, human and financial resources into science and education. Such a conclusion initiated a new analysis of education in the US, increased investment in education, and encouraged the reform of education and the education system. Education in the US became a political issue predetermined for economists, politicians and experts from different fields of science and significantly less so for pedagogues. ${ }^{5}$

As a result of these events, in 1959, the Woods Hole Conference was held in Massachusetts, USA. The conference, under the leadership of Jerome Bruner, brought together 34 experts from mathematics, biology, psychology, and the like (the fewest experts were from the field of pedagogy) (Bruner, 1999). Conclusions of the conference went in the direction of 'technical' and behavioural approaches to education and curricula and focusing on organising teaching that enabled 'effective' learning. The implications of this conference also emphasised teaching STEM areas, but also on teaching via scientific methods (i.e., inquiry-based learning). These events initiated a technocratic approach towards the change and development of educational reform and curricular changes in the US.

Consequently, learning and learning outcomes began to be seen as products that can be expertly produced by appropriate instruction. Furthermore, a technocratic approach began to manifest itself in the dominance of

5 A well-known statement from that time by US Economic Counsellor Walter Heller at the first OECD Education Conference: 'May I say, that, in this context, the fight for education is too important to be left solely to the educators' (OECD, 1961, according to Tröhler, 2013a). 
decision-making in education (education system) by economic, economic, and political experts, not by educators (Tröhler, 2014). Thus began a substitution of teachers and educators, starting with the so-called experts for education. Successively to these processes in educational policy, a dominance of significant financial investments in education began, which triggered a process of economising the education. In other words, the premise formed that one could boost economic prosperity and take leadership in the Cold War race with the USSR by increasing financial investment in education.

The Cold War race resulted in the reduction of socio-humanistic teaching content, and the implementation of content from the STEM area (Autio, 2017). Emphasis was placed on teaching content from the field of mathematics, natural sciences and foreign languages. Parallelly, the technocratic approach categorised the directions and movements of reform (progressive) pedagogy, in general, the significance of John Dewey's ideas in the US, as inappropriate for teaching in the context of the Cold War (Autio, 2017; Tröhler, 2011). This is also the beginning of stagnation of the development and expansion of reform pedagogy on a global level.

Technocratic and economic approaches and the need for 'effective' learning updated the behavioural approach to teaching. Behavioural psychology took the lead in the organisation of teaching and learning. That is especially significant because attempts were undertaken to make learning as a product operational, visible, and measurable. The behavioural approach of stimulation and reaction (S-R) enabled (apparently) the premise that with precise (effective) teaching one caused exactly the desired learning and outcomes, and then in terms of visible actions, one makes it perceptible and measurable. This approach supported teaching in which students are offered factual knowledge that is specifically controlled and approved. This kind of system, with proper control, could successfully achieve the implementation of the set goals. Thus, the constructed curriculum does not allow freedom to students or teachers: it is managed mostly from the outside (via other educational institutions). By understanding the didactics, and by using the theory of curriculum, we come to the knowledge that there is no so-called 'curricular didactic model' because, according to these two terms, such terminological determination would not have any particular sense (Möller, 1992). Therefore, it is handled as a target-oriented approach. This model was inspired by the behaviourism-oriented works of Skinner, Tyler, and Bloom.

Consequently, it is not surprising that military psychologists Jerome Bruner, Torsten Husén, Skinner, Robert Gagné, Leslie Briggs, John Flanagan et al. (Reiser, 2001; Tröhler, 2013a) were given the task of organising the teaching 
in the Cold War context; those psychologists had established behaviourism in learning, while training soldiers in World War II. In this regard, especially in the military perspective, the original pedagogical educational dimension of learning and teaching is negligible. Skills and cognitive abilities are of importance, and they can be developed via exercising (drill). This has significantly contributed to the processes of the psychologisation of education. Based on these premises, one can say that the philosophy of education has been eliminated from education and been by the psychology of education.

With the processes of psychologisation and technocration, and especially the economisation of education, financial investments had to be profitable. Thus began the standardisation of education in the US, above all of the learning outcomes and their evaluation. In this respect, standardised national external evaluations came to life. This degraded the role of the teaching profession, as evaluation was an immanent element of it (Autio, 2017). Thus, feedback to the authorities on the effects of investing in education as well as the (apparent) possibility of prediction of certain social, military, political, and economic trends was formed.

Immediately after the Second World War, in favour of the psychologisation of education, the formation of the basic components of the curriculum (i.e. Tyler's Rational) also took place. This also favoured Bloom's formation of taxonomy (Doll, 1993). Alongside the technocratic and expert approach, by implementing curricular content of the STEM area and by economising, standardising and educating psychologists, the implicit educational form of the Cold War influence has taken its manifest form, which will later be implicated in curricula and educational reforms at both the national and global levels.

\section{Cold War Implications in Curricula and Educational Reforms}

One collateral element of the Cold War was the formation of the Organization for Economic Co-operation and Development (OECD) in 1961. According to Tröhler (2014), the OECD is the successor of the Organization for European Economic Development (OEEC), which was initially founded for the development of European states. Due to the internal trade opposition of individual European states, the OEEC expanded to non-European countries, primarily Canada and the US (Tröhler, 2014). That also made the US the leader of the idea of international development. ${ }^{6}$ Although the OECD was not conceived as a Cold War element, with the dominance of the US, it became an instrument of

6 Just as the USSR was the leader of the Warsaw Pact, i.e. the Eastern bloc. 
the competition between the NATO Pact and the Warsaw Pact. That is evident from it directing its action to assisting in the development of underdeveloped, non-aligned countries, but also those in danger of the USSR influence (Tröhler, 2014). Soon the OECD also became focused on education, which had been labelled as a predictor of economic development. This placed the management of education policies at an international level, i.e. the process of globalisation of education was stimulated. In this regard, Sing (2002) points out that the globalisation wave encompassed all spheres of individual life and became the centre of interest of all sciences (early $21^{\text {st }}$ century). In this regard, it is possible to follow the role of globalisation, which has been offered to smaller countries such as Croatia, as a possibility and/or, which in this context primarily refers to education at all levels.

In contrast, parallel to the globalisation of education and the Cold War meddling in education, with the premise of education being an element of the Cold War race as well as a predictor of economic development, what has recently been called the pedagogisation of social problems began (Germ. Pädagogisierung) (Smeyers \& Depaepe, 2008). The pedagogisation of (all) social problems is to perceive (mainly by the state administration) that educational actions (education, schools, educational institutions, lifelong learning) can solve (all) social problems (health, cultural, financial, etc.).

Symptomatic to all of the mentioned Cold War phenomena in curricula and educational reforms, PISA (Programme for International Student Assessment) was formed and developed in the last two decades. The PISA evaluation was established by the OECD to measure and compare the individual competencies of 15 -year-olds and the prediction of economic development. What is also crucial regarding PISA evaluation, in relation to the Cold War tendencies of the US education policy in the middle of the previous century, and then the globalisation under the auspices of the OECD, is its focus that is put solely on competences and content in the fields of mathematics, natural sciences, and languages. Also, one of the implications of the Cold War is also seen in what is called the medicalisation of education (Tröhler, 2016). The medicalisation of education started in the 1970s and 1980s, and it signifies the substitution of educational research paradigm with the biological and medical research paradigm. This is particularly noticeable because the Centre for Educational Research and Innovation (CERI) is one of the institutions that is conducting such analyses, and the OECD participated in the formation of CERI in 1968 (Tröhler, 2016).

The Cold War pedagogisation of all social problems was seen especially in the reforms of the educational systems of individual states but guided by national globalist policies. In other words, the implications of the Cold War 
are also reflected in educational reforms that have largely been accepted and adapted to the US tradition, which advocated a curriculum in which everything would be measurable, starting from the learning outcomes through grade scales, and curricular research itself. It is interesting that the standardisation, quantification, and economisation of education as a panacea of economic and Cold War political problems led to the need for a new wave of educational reforms. The famous Coleman Report ${ }^{7}$ (1966) and Jencks Report (1972) have shown that investing in education did not provide the expected results, which required new educational reforms. A few years later, at the beginning of the 1980s, a report titled A Nation at Risk (1983) was issued, and it indicated that the educational system in the US, under the influence of particularly negative Cold War relations and the current economic crisis, did not meet the economic (and Cold War) needs. That triggered new reforms in the US. However, interestingly, under the influence of globalisation, the pedagogisation of social problems, the standardisation and economisation of education, as well as the implicit influence of the OECD, reforms around the world began. To support this interpretation of the implications of the Cold War in reforms, Sahlberg (2011) suggests that the Global Educational Reform Movement (GERM) began in the early 1980s. GERM is a manic global reformation of educational systems under the influence of the standardisation of education, standardised measurement, the privatisation and economisation of education, in which curricula are forced to include the implementation and evaluation of content and knowledge in mathematics, natural sciences and languages (Autio, 2017). The global reforms of national education systems mainly failed to achieve the desired results because they did not respect the social, cultural, and historical features of individual nations. Matijević and Rajić (2015) warn that most of the changes that took place in the school system and the teaching mainly referred to change of the duration of the elementary and/or obligatory school, and introducing or leaving behind some teaching courses, while classroom teaching (together with Educational Ecology) has largely followed the logic of frontal teaching. Significant changes also did not occur by introducing modern technologies (LCD projectors, PowerPoint presentations, and smart boards) into classes.

In contrast, Finland is one of the few countries that had success with its reforms; it implemented a successful educational reform by focusing more on the activities of students related to technology, handcrafts, and visual arts (19 hours a week or 684 lessons hours during compulsory schooling) (Matijević \& Rajić, 2015). Finland has done the opposite of everything that OECD expected via

7 For a detailed insight into the significance of Coleman's reports, see the special issue of CEPS Journal (Sardoč \& Gaber, 2016). 
PISA. The Finns put an emphasis on socio-humanistic contents in curricula, neutralised standardisation, moved away from the behavioural theory of learning, maintained the culture of the philosophy of education (and not the psychology of education), provided teachers with autonomy, and implemented elements of the direction and movement of the reform pedagogy in state schools (Autio, 2017; Sahlberg, 2011). Sahlberg (2011) systematises the reform of the Finnish educational system and stresses that the reforms that are being implemented are directed towards the needs of teachers and students, not just the needs of society. Reforms in Finland continue and in the direction of halting the trend of increasing inequalities within schools and between schools, establishing regional equality and improving learning outcomes (Ouakrim-Soivio, 2016).

\section{Methodological transformation}

In addition to playing a significant role in curricular and educational reforms, the Cold War also had an impact on the research approaches and methodological frameworks of pedagogical research. The present situation in the research of the pedagogical and didactic phenomena is mainly due to the positivist approach, which asserts in the possibility of a correct understanding of natural and social phenomena, and that the basic task of science is to discover the real nature of reality and its true functioning. Such research has the purpose of achieving an objective understanding of reality based on empirical data. The situation in the research of pedagogical phenomena (especially in the Croatian context) was mentioned earlier by Jagić (2007), Dubovicki (2017) and Dubovicki, Mlinarević, and Velki (2018). Jagić (2007) emphasises that the results of pedagogical research are not to be reduced to statistical indicators (which are the qualities of the positivist paradigm), but that it is necessary to use qualitative data and, at best, a combination of both. Gorard and Taylor (2004) particularly emphasise the importance of data obtained by combining the methods, pointing out that the lack of one research method can be compensated by supplementing another research method, contributing to the credibility of the obtained results.

The positivist approach uses methods that enable accurate measurement, as well as hypothesis testing, which is also a Cold War heritage. Bognar (2012) also writes about the potential dangers of such research and suggests that it can lead to a complete separation of pedagogical theory and practice.

It is necessary to advocate neopositivism (which implies the existence of a reality independent of men), and also a constructivist approach in the research of pedagogical and didactic concepts. Research use different perspectives 
and approaches when it comes to defining the research goals, and the choice of research questions and methods. In a constructivist approach, the researcher himself, via placing himself in the research, attempts to answer the legality, questions and dilemmas that have been set in the research. Pedagogy in the postmodern period does not advocate the rejection of all those approaches that had previously been developed in the methodology but also does not advocate choosing just one of them, however, it does advocate an effort to leave behind an exclusively positivist approach that comes down to finding the problems that exist. In other words, by advocating the pluralism of scientific paradigms (Bognar 2012; Dubovicki, 2017), we create conditions in which it is possible not only to explore (detect) the pedagogical problem (positivist approach) but also to point to the causal and consequential implications of particular phenomena, to critically review the results of previous research (critical theory), to influence their change (postpositivist approach) and to participate personally (participatory paradigm ${ }^{8}$ ) in changes occurring in the educational process with particular emphasis on researching and improving the educational component of teaching.

\section{The Importance and role of Humanistic Curriculum}

The curricular approach in technical (i.e. scientific) perspective, established in the Cold War circumstances, emphasising the processes of learning rather than education, behavioural approaches, and the operationalisation of teaching aims received negative reviews in the German didactic tradition in the 1970s (Giesecke, 1993; Winkel, 1994). That is why it is essential to emphasise the importance of the didactic, traditionally German thought on education, especially when the didactic is considered as the theory of education in the original meaning of the term 'education' (Bildung) in German language, culture, and didactic perspective (Autio, 2017), in which Bildung represents the formation of a free, autonomous, self-critical, socially responsible, moral and proactive person (Autio, 2017), or humanistic approaches to the curriculum through education.

The curricula will be structured in relation to the preferred orientation, and the realisation of the set goals (learning outcomes) will be organised accordingly. We can say that if the curriculum were oriented towards the positions of perennialism and/or progressivism, an orientation towards the humanistic approach would be the closest because the philosophy of these directions favours the development of the whole person and respecting his/her the interests and needs (Table 1 ).

8 Action research has the most significant role in the participatory paradigm. 
Table 1

Theories of education

\begin{tabular}{|c|c|c|c|c|}
\hline Theory & Aim & Curriculum & $\begin{array}{l}\text { Educational } \\
\text { implications }\end{array}$ & Representatives \\
\hline $\begin{array}{l}\text { Perennialism } \\
\text { (based on } \\
\text { realism) }\end{array}$ & $\begin{array}{l}\text { Education } \\
\text { of a rational } \\
\text { person }\end{array}$ & $\begin{array}{l}\text { Hierarchical orientation } \\
\text { towards cultivating the } \\
\text { intellect, in other words, } \\
\text { a curriculum oriented in } \\
\text { the positions of peren- } \\
\text { nialism takes systematic } \\
\text { care of the education } \\
\text { and training of its sub- } \\
\text { jects by providing the } \\
\text { necessary conditions } \\
\text { (literacy, space, time) } \\
\text { and focuses on perma- } \\
\text { nent education }\end{array}$ & $\begin{array}{l}\text { Focus on the care } \\
\text { of permanent } \\
\text { education as we } \\
\text { can see in the great } \\
\text { works of Western } \\
\text { cultural heritage }\end{array}$ & $\begin{array}{l}\text { Adler } \\
\text { Bloom } \\
\text { Hutchins } \\
\text { Maritain }\end{array}$ \\
\hline $\begin{array}{l}\text { Essentialism } \\
\text { (based on } \\
\text { idealism and } \\
\text { realism) }\end{array}$ & $\begin{array}{l}\text { Education of } \\
\text { a practical } \\
\text { and compe- } \\
\text { tent person }\end{array}$ & $\begin{array}{l}\text { Focused on providing } \\
\text { the basis of education: } \\
\text { reading, writing and } \\
\text { calculation of all its } \\
\text { subjects }\end{array}$ & $\begin{array}{l}\text { Focus on skills and } \\
\text { subjects that trans- } \\
\text { mit cultural heri- } \\
\text { tage and contribute } \\
\text { to socio-economic } \\
\text { efficiency. }\end{array}$ & $\begin{array}{l}\text { Bagley } \\
\text { Bestor } \\
\text { Conant } \\
\text { Morrison }\end{array}$ \\
\hline $\begin{array}{l}\text { Progressivism } \\
\text { (based on } \\
\text { pragmatism) }\end{array}$ & $\begin{array}{l}\text { Education of } \\
\text { an individual } \\
\text { according } \\
\text { to their } \\
\text { interests and } \\
\text { needs }\end{array}$ & $\begin{array}{l}\text { Curricular content is ori- } \\
\text { ented towards students' } \\
\text { activities and projects }\end{array}$ & $\begin{array}{l}\text { Providing instruc- } \\
\text { tions which include } \\
\text { problem-solving } \\
\text { and group activi- } \\
\text { ties, the professor } \\
\text { encourages student } \\
\text { activities through } \\
\text { his activities }\end{array}$ & $\begin{array}{l}\text { Dewey } \\
\text { Johnson } \\
\text { Kilpatrick } \\
\text { Parker } \\
\text { Washburne }\end{array}$ \\
\hline $\begin{array}{l}\text { Socio- recon- } \\
\text { structionism } \\
\text { (based on } \\
\text { pragmatism) }\end{array}$ & $\begin{array}{l}\text { Reconstruc- } \\
\text { tion of } \\
\text { society }\end{array}$ & $\begin{array}{l}\text { This approach to the } \\
\text { curriculum emphasises } \\
\text { the use of social scienc- } \\
\text { es as a reconstructive } \\
\text { tool for studying socio- } \\
\text { economic problems }\end{array}$ & $\begin{array}{l}\text { Focus on the crucial } \\
\text { socio-economic } \\
\text { problems of society. }\end{array}$ & $\begin{array}{l}\text { Brameld } \\
\text { Counts } \\
\text { Stanley }\end{array}$ \\
\hline
\end{tabular}

Note. Adapted from Ornstein \& Levine, 1989, p. 205.

The dominance of a particular theoretical approach is extremely important because the practice relies on the theory from which it starts; therefore, we can conclude that the organisation and performance of the teaching will take place in the spirit of the dominant theoretical approach. Depending on what we want to encourage and achieve in teaching, we will decide upon one of the theoretical approaches that will, in its conception, advocate the idea that should be achieved via teaching that is organised in such a way.

Regarding the theoretical-methodological approach, the present paper emphasises the humanistic approach to curriculum, which is individual-oriented and advocates the concept of open teaching, which enables a creative 
approach. A humanistic approach to the curriculum advocates the possibility of learning in a new way: partner, active, collaborative, creative with a comfortable emotional and democratic social climate. Teaching should go hand in hand with the individual student's opportunities and allow the student to grow into the fullness of his potential.

A humanistic curriculum focused on development advocates a pedagogically open approach that is aimed at all participants of the teaching process. This curriculum concept advocated the importance of today's schools and faculties to become more of an educational-social community in which students should be provided with learning opportunities in a new way: with the help of creative activities, a pleasant educational climate and with an emphasis on realising the full potential of each participant of the educational process. Schools and faculties that support this curriculum concept will go hand in hand with the individual capabilities of each student, but will also develop all types of intelligence (Gardner, 1993).

The role of all participants in curriculum development and implementation should be such as to contribute to the development, creation, implementation, and evaluation of the curriculum, as well as the promotion of human knowledge. The role of a teacher (university professor) in the new curriculum should be focused on encouraging students to have an active and critical relationship towards knowledge, the ability to reorganise their existing knowledge, to look for its application, to identify their problems and to resolve their problematic abilities (Sekulić-Majurec, 2007).

It is believed that a key feature of the contemporary curriculum would undoubtedly be an implementation (both in theory and practice) of humanistic theory that advocates the growth and development of every individual, but also satisfying his interests and needs. The curriculum that would be based on humanistic theories would follow the demands coming from the inside (listening to the needs of all participants in the teaching process) but also respect the current social demands. The curriculum that would systematically take care of promoting creativity would be open and flexible and would be created in a living process as the answer to the needs of those who participate in it.

\section{Conclusion}

Theoretical-comparative and historical analysis of the role of the Cold War in the formation of contemporary curricula and the encouragement of educational reforms can offer several conclusions. Namely, the 'Sputnik shock' launched the military race of the Cold War for arms and the space race: since 
then, education began to be seen as a mechanism of achieving the desired goals, which triggered the process of the pedagogisation of social problems. The Cold War race influenced the reduction of socio-humanistic content from the curriculum and their substitution with the content from the STEM area, and stopped the developing and spreading the directions and movements of reform pedagogy. Because of the heavy financial investment in education, learning began to be perceived as a product and, to successfully promote it in teaching, a behaviourism approach was necessary. That created the psychologisation of education, which displaced the philosophy of education in didactics. In other words, education was replaced by learning. That also resulted in the premise that learning can be stimulated by certain instruction activities, and the learned can be measured by standardised tests. The premise that education can influence the takeover of the leading position in the Cold War race led to profitable financial investment in education: the economisation of education. Due to the desire to test economic feasibility, the standardisation of education was formed.

The formation of certain supranational economic institutions, such as the OECD, led to the globalisation of education, while recently we have been speaking about the medicalisation of education due to the increasing substitution of educational research in teaching with biological and medical research paradigms (positivism). Processes of psychologisation, economisation, globalisation and education standardisation led to a series of reforms of education systems that move in the direction of supranational (GERM) rather than adequate national education policies. Parallel to this, the OECD formed PISA, which, as with the Cold War educational policy of the USA (and the USSR), emphasises the mathematical, natural and linguistic field. In addition, PISA incorporates the standardisation, economisation, psychologisation, and globalisation of education. Likewise, for measurability, standardisation, and economisation, the methodological shift in education also took place, with an emphasis on the quantitative positivist approach. The Cold War also influenced research in pedagogy, so until today, in the research of education, the positivist approach continues to dominate, and it requires researchers to accurately measure and use statistical stunts that have the purpose of detecting the problem rather than fully researching it, and most importantly, affect its change, directly in practice.

In contrast, the open curriculum would certainly be the one curriculum that would have been a feature of the humanistic approach, would create optimal conditions for stimulating creativity, and would not be a 'slave' to the strict execution of the prescribed measures. Such a curriculum would, in its concept, independently implement the contents and activities that are considered primary and desirable (primarily for students and teachers, and secondary for 
society as a whole), and its priorities would vary from year to year. A developmentally-oriented humanistic curriculum is one that can influence the changes in the quality of learning, but also the changes in personality traits and individual development; it also emphasises some elements of the Bildung concept. The benefit of the humanistic approach to the curriculum is proven by the Finnish success in initial PISA evaluations. The Finnish education system achieved outstanding results at PISA, from an education system diametrically opposed to what PISA and globalisation education reforms expect. The Finns emphasised social and humanistic teaching contents, national needs, moved away from a behavioural approach, incorporated elements of reform pedagogy, neutralised standardisation, placed great emphasis on the philosophy of education and the autonomy of the teacher. Precisely such a concept of modern curricula and educational reforms could be one of the guidelines for conducting national education policies of individual countries.

The results of this theoretically-comparative and historical analysis can also be used for practical purposes. Namely, the conclusions can serve as guidelines for critical thinking of the operationalisation of learning outcomes, questioning of measuring and evaluating the effective area of outcomes, and focusing on the importance of the humanistic relationship between the teacher and the student. Bearing in mind the experiences of history, it is essential to focus on the humanistic approach in future curricular concepts that will advocate the integral development of each individual participant of the teaching process, especially on satisfying the interests (cognitive, experiential and psychomotor) and the needs (biological, social and self-actualisation), encouraging the development of divergent thinking and creativity.

Finally, it is worth pointing out that although the interpretations, definitions, explanations and conceptualisations show that there is a slightly controversial legacy of the Cold War in education, that should not be analysed from a negative point of view (as well as the unquestionable positive contribution of PISA, CERI and OECD to the global education) but should rather be seen as an incentive for further reflection on and improvement of modern curricula and educational reforms.

\section{References}

Autio, T. (2017). Curriculum theory in contestation? American curriculum, European didaktik, and Chinese wisdom traditions as hybrid platforms for educational leadership. In M. Uljens \& R. M. Ylimaki (Eds.), Bridging educational leadership, curriculum theory and didaktik (pp. 257-282). Cham: Springer. 
Bognar, B. (2012). Pedagogija na putu prema pluralizmu znanstvenih paradigmi i stvaralaštvu [Pedagogy on the way towards pluralism of scientific paradigms and creativity]. In N. Hrvatić \& A. Klapan (Eds.), Pedagogija i kultura, Svezak 1 (pp. 101-111). Zagreb: Hrvatsko pedagogijsko društvo. Bognar, L. (2012). Pedagogija kao odraz postojećeg ili kreiranje mogućeg [Pedagogy like reflection of existing or creating of possible]. In N. Hrvatić \& A. Klapan (Eds.), Pedagogija i kultura, Svezak 1 (pp. 112-122). Zagreb: Hrvatsko pedagogijsko društvo.

Bruner, J. (1999). The process of education. Cambridge, MA: Harvard University Press.

Coleman, J. S. (1966). Equality and educational opportunity. Ann Arbor, MI: Inter-University Consortium for Political and Social Research.

Doll, W. E. (1993). Postmodern perspective on curriculum. New York, NY: Teachers CollegePress. Domović, V. (2009). Kurikulum - osnovni pojmovi [Curriculum - key concepts]. In V. Vizek Vidović (Ed.), Planiranje kurikuluma usmjerenog na kompetencije u obrazovanju učitelja i nastavnika: priručnik za visokoškolske nastavnike (pp. 19-32). Zagreb: Filozofski fakultet Sveučilišta u Zagrebu. Dubovicki, S. (2017). Futurološke metode istraživanja [Futuristic research methods (or research methods of the future?)]. In S. Opić, B. Bognar, \& S. Ratković (Eds.), Novi pristupi metodologiji istraživanja odgoja (pp. 203-221). Zagreb: Učiteljski fakultet Sveučilišta u Zagrebu.

Dubovicki, S., Mlinarević, M., \& Velki, T. (2018). Istraživački pristupi i metodološki okviri u istraživanjima budućih učitelja [Research approaches and methodological framework in the research of future teachers]. Nova prisutnost, 16(3), 595-611. doi:10.31192/np.16.3.11

Evans, R. W. (2011). The hope for American school reform: The Cold War pursuit of inquiry learning in social studies. New York, NY: Palgrave Macmillan.

Gardner, H. (1993). Multiple intelligences. New York, NY: Harper Company.

Giesecke, H. (1993). Uvod u pedagogiju [Introduction in pedagogy]. Zagreb: Educa.

Glatthorn, A. A. (2000). The principal as curriculum leader: Shaping what is taught and tested.

Thousand Oaks, CA: Sage.

Gorard, S., \& Taylor, C. (2004). Combining methods in educational and social research. Maidenhead,

UK: Open University Press.

Gudjons, H. (1993). Pedagogija: temeljna znanja [Pedagogy: Key concepts]. Zagreb: Educa.

Hartman, A. (2008). Education and the cold war: The battle for the American school. New York, NY:

Palgrave Macmillan.

Hrvatić, N., \& Piršl, E. (2007). Kurikulum pedagoške izobrazbe učitelja [Curriculum of pedagogical teachers training]. In V. Previšić (Ed.), Kurikulum - teorije, metodologija, sadržaj, struktura (pp. 385-412). Zagreb: Školska knjiga.

Jagić, S. (2007). Problem kauzalnosti u pedagogijskom istraživanju [The problem of causality in educational research]. In V. Previšić, N. N. Šoljan, \& N. Hrvatić (Eds.), Pedagogija prema cjeloživotnom obrazovanju i društvu znanja, Svezak 1. (pp. 58-67). Zagreb: Hrvatsko pedagogijsko društvo.

Jencks, C. et al. (1972). Inequality: A reassessment of the effect of family and schooling in America. New York, NY: BasicBooks. 
Marsh, C. J. (2004). Key concepts for understanding curriculum. London, UK \& New York, NY:

Routledge-Falmer.

Matijević, M., \& Rajić, V. (2015). Metodologije kurikulumskih promjena: nekad i danas

[Methodology of curricular change: Then and now]. In S. Opić \& M. Matijević (Eds.), Istraživanja

paradigmi djetinjstva, odgoja i obrazovanja, IV. simpozij: Nastava i škola za net-generacije: Unutarnja reforma nastave u osnovnoj i srednjoj školi (pp. 635-654). Zagreb: Učiteljski fakultet, Sveučilišta u

Zagrebu.

Mijatović, A. (1996). Kurikulum kao okosnica osuvremenjivanja odgoja i obrazovanja [Curriculum as the basis of modernizing education]. In Zbornik radova Prvog sabora pedagoga Republike Hrvatske (pp. 69-76). Zagreb: HPKZ.

Milat, J. (2005). Pedagoške paradigme izrade kurikuluma [Pedagogical paradigms of curriculum construction]. Pedagogijska istraživanja, 2(2), 199-208.

Miljak, A. (2005). Su-konstrukcija kurikuluma i teorije (ranog odgoja) obrazovanja [Co-construction of curriculum and theories of (early) education]. Pedagogijska istraživanja, 2(2), 235-251.

Möller, C. (1992). Didaktika kao teorija kurikuluma [Didactics as theory of curriculum]. In H.

Gudjons, R. Teske, \& R. Winkel (Eds.), Didaktičke teorije (pp. 73-88). Zagreb: Educa.

Ornstein, A. C., \& Levine, D. U. (1989). Foundationd of Education. Boston, MA: Houghton Mifflin

Company.

Ouakrim-Soivio, N. (2016). Basic education of the future: Let's turn the trend! Croatian Journal of

Education 18(1), 133-152. doi:10.15516/cje.v18io.2222

Pinar, W. F. (2003). International handbook of curriculum research. London, UK: Lawrence Erlbaum Associates Publihers.

Poljak, V. (1984). Didaktičke inovacije i pedagoška reforma škole [Didactical innovations and pedagogical reform of school]. Zagreb: Školska knjiga.

Reiser, R. A. (2001). A History of instructional design and technology. Part II: A history of instructional design. Educational Technology, Research and Development, 49(2), 57-67.

Rudolph, J. (2002). Scientists in the classroom: The Cold War reconstruction of American science education. New York, NY: Palgrave Macmillan.

Sardoč, M., \& Gaber, S. (2016). The legacy of the Coleman report (Editorial). CEPS Journal, 6(2), 5-8. Sahlberg, P. (2011). Finnish lessons: What can the world learn from educational change in Finland. New York, NY: Teachers College Press.

Sekulić-Majurec, A. (2007). Uloga sudionika odgojno-obrazovnog procesa u stvaranju, provedbi i vrednovanju kurikuluma [Role of actors in educational process - creating, apllicationing and evaluation of curriculum]. In V. Previšić (Ed.), Kurikulum - teorije, metodologija, sadržaj, struktura (pp. 351-383). Zagreb: Školska knjiga.

Sing, H. (2002). Utjecaj globalizacije na manje zemlje te uloga manjih zemalja u procesu globalizacije: primjer socijalne politike i socijalnog rada [The impact of globalisation on smaller countries and the role of smaller countries in the process of globalisation: The example of social policy and social work]. Revija za socijalnu politiku, 9(1), 23-32. 
Smeyers, P., \& Depaepe, M. (Eds.). (2008). Educational research: The educationalization of social problems. Berlin: Speinger.

Smith, M. K. (2000). Curriculum theory and practice. In The encyclopaedia of informal education. Retrieved from www.infed.org/biblio/b-curric.htm Tanner, D., \& Tanner, L. (1980). Curriculum development: Theory into practice. New York, NY: Macmillan.

Topolovčan, T., Rajić, V., \& Matijević, M. (2017). Konstruktivistička nastava: teorija i empirijska istraživanja [Constructivist teaching: Theory and empirical research]. Zagreb: Učiteljski fakultet Sveučilišta u Zagrebu.

Tröhler, D. (2011). Languages of education. Protestant legacies, national identities, and global aspirations. New York, NY \& London, UK: Routledge.

Tröhler, D. (2013a). The technocratic momentum after 1945, the development of teaching machines, and sobering results. Journal of Educational Media, Memory, and Society, 5(2), 1-19.

Tröhler, D. (2014). Change management in the governance of schooling: The rise of experts, planners, and statistics in the early OECD. Teachers College Record, 116, 1-26.

Tröhler, D. (2016). The medicalization of current educational research and its effects on educational policy and school reforms. Discourse: Studies in the Cultural Politics of Education, 36(5), 749-764. Tröhler, D., \& Barbau, R. (Eds.). (2011). Education systems in historical, cultural, and sociological perspectives. Rotterdam: Sense Publishers.

United States. National Commission on Excellence in Education. (1983). A nation at risk: The imperative for educational reform: A report to the Nation and the Secretary of Education, United States Department of Education. Washington, DC: The Commission.

Walker, D. F. (2003). Fundamentals of curriculum: Passion and professionalism. Mahwah, NJ:

Lawrence Erlbaum Associates.

Wiles, J., \& Bondi, J. (1998). Curriculum development: A guide to practice. Mishawaka, IN: Prentice Hall.

Winkel, R. (1994). Didaktika kao kritička teorija nastavne komunikacije [Didactics as critical theory of teaching communication]. In H. Gudjons, R. Teske, \& R. Winkel (Eds.), Didaktičke teorije (pp. 95-116). Zagreb: Educa.

Wojtczak, A. (2002). Glossary of medical education terms. Retrieved from http://www.iime.org/ glossary.htm

Zimmerman, W. (1997). Curriculum - Konstruktion. Klinkhardt: Bad Heilbrunn. 


\section{Biographical note}

Tomislav Topolovčan, $\mathrm{PhD}$, is an Assistant Professor in the field of didactics on the Faculty of Teacher Education, University of Zagreb, Croatia. His scientific interest is focused on general didactics, curriculum research, neurodidactics, media didactics and qualitative and quantitative research methods in education.

Snježana Dubovicki, PhD, is an Assistant Professor in the field of didactics at the Faculty of Education, Josip Juraj Strossmayer University of Osijek, Croatia. Her scientific interest is focused on curriculum research, teaching at all levels of education (with particular emphasis on university teaching and lifelong learning), creativity, self-actualization, emotions in teaching, qualitative methodology, futurology in education and futurology research methods. 